\title{
A COMPARISON OF ACTUAL AND POTENTIAL FOREST LAND PRODUCTION IN SASKATCHEWAN
}

\author{
By A. KABZEMS and J. P. SENYK ${ }^{1}$ Oxf. $524.61(712.4)$
}

\section{$A B S T R A C T$}

A comparison is made between actual and potential forest production of a forest area in Saskatchewan. This area is described as to location, physiography, main land characteristics and broad land form--forest relationships.

\section{INTRODUCTION}

The purpose of this article is to emphasize the difference existing between the present actual and the potential forest production on 1.8 million acres of Provincial Forest Land in north central Saskatchewan.

The forested region detailed on map sheet $73 \mathrm{H}$ was chosen primarily because it was the initial area in Saskatchewan where the Land Capability for Forestry survey was completed in 1966; thus for the first time potential production data became available for comparison with up-to-date forest inventory figures on a large area.

Secondly, ecologically, this area represents average growing conditions in the Province.

Location and Physiography

The study area is in the Northern Provincial Forest and constitutes a portion of one topographic map sheet $-73 \mathrm{H}$, Prince Albert. (Co-ordinates $53^{\circ}$ and $54^{\circ} \mathrm{N}$. latitude, $104^{\circ}$ and $106^{\circ}$ longitude).

Physiographically, it is located within the Great Plains Province of the Interior Plains of North America. On a regional level, it lies partly within the Manitoba-Saskatchewan Lowlands, the Saskatchewan Plains and the Saskatchewan Uplands respectively (1). The topography is gently rolling with few areas of pronounced relief. Elevations range from approximately 1,200 to 2,000 feet above sea level.

Fifty-five year weather records at Prince Albert, located in the south west corner of the map sheet, indicate a mean annual temperature of $33^{\circ} \mathrm{F}$. with an average frost free period of 90-100 days (10). Average annual precipitation is 16 inches, or 40.6 centimetres, three quarters of which falls during the period April to October. The average potential evapotranspiration is 40.1 centimetres. These figures indicate a moisture surplus of only $0.5 \mathrm{~cm}$. The driest months are September and October (9).

The most common surficial deposit is glacial till of medium texture which allows moderate drainage. Closely associated with the glacial till are glaciofluvial depopsits. These deposits in the form of outwash sands and gravels are, as a rule, very rapidly drained. Glacio-lacustrine silts and clays occur mainly as shallow overlays on till. The moisture regime of such overlayed till ranges from well to poorly drained. Recent alluvial soils, mostly fine textured sands and silts, are poorly to moderately well drained. These deposits occur locally in present drainage channels, and are not extensive. Aeolian

${ }^{1}$ Foresters, Department of Natural Resources, Forestry Branch, Prince Albert, Saskatchewan. 
deposits, mostly wind-worked glacio-fluvial materials occupy considerably large areas adjacent to the South and North Saskatchewan Rivers. These deposits are well to rapidly drained. Organic soils occur as shallow to deep peat accumulations in poorly drained depressions.

\section{LAND AND FOREST RELATIONSHIPS}

The established natural forest cover types of the study area are those common to Section B17 - Aspen Grove, and Section B18 a - mixedwood, of the Boreal Forest Region (7), within which it is located. Pure aspen stands predominate to the exclusion of almost all other species within the Aspen Grove Section, while aspen-white spruce association with varying proportions of aspen is a typical and prominent cover type of the mixedwood section. With the exception of lodgepole pine and bur oak, all the other commercial tree species native to Saskatchewan occur in varying proportions in this latter section.

Since the Aspen Grove section covers only a small portion on the south boundary of the study area and because one species predominates there, concentration of effort was centred on that part of the area classified as mixedwood, with its varied soil and stand compositions.

White Spruce-Picea glauca (Moench) Voss, occurring in pure stands, has a fairly wide range of growing conditions. It is common on fine to coarse textured glacial till with dry to wet moisture conditions, but attains its most luxurious growth on moderately to well drained alluvial-lacustrine deposits (130 feet at 100 years of age).

The Mixedwoods or white spruce-aspen Picea glauca Moench Voss and Populus tremuloides Michx, cover type occurs under conditions similar to pure white spruce.

Jackpine-Pinus banksiana Lamb is the most commonly growing tree species on fine to coarse textured glacio-fluvial material, modified till, alluvium and aeolian deposits in moderately well drained to rapidly drained positions.

Black Spruce-Picea mariana Mill B.S.P. grows on a variety of soil textures and deposits, but predominantly in low lying areas and depressions in which there has been rather extensive raw humus or peat accumulation. Following severe forest fires, it establishes itself on upland sites where moisture is adequate.

Tamarack-Larix laricina Du Rpi K. Koch occurs entirely on wet saturated organic soils.

Three other commercial tree species: Balsam Fir-Abies balsamea (L) Mill, Black Poplar - Populus balsamifera (L), and White Birch Betula papyrifera Marsh, grow fairly well in this area, but are generally minor components in mixed stands, comprising only one to three percent of the total merchantable volume.

Balsam fir and white birch are not included as rating species in the survey because of their minor occurrence and present low economic value. Black poplar, however, is used because it occupies a rather unique niche in certain areas where site conditions best suit this species.

The distribution of present forest cover types and their stocking classes is illustrated in Table 1. In Saskatchewan's forest inventory survey, forest stands on productive land have been classified into nine cover types by 
species composition; into four height classes on the average height of dominant trees within the stand, and into four density or stocking classes based on the percentage of tree crown closure (10). Combinations of the above factors in all possible situations yield 144 basic or original cover types. However, three broad cover type groups such as softwood, mixedwood, hardwood, and four levels of stand density seem to be sufficient to adequately characterize the present growing stock and produce a fair conception of how efficiently the land space is utilized under existing stands.

It might also be in order to explain the terminology used in the stand density descriptions in Table 1 . When such popular terminology is used, it usually carries with it a fairly precise local meaning and range of values. In Saskatchewan, using the number of trees and basal area as stand density criteria, the following standards are recognized:

\begin{tabular}{|c|c|c|c|}
\hline & \multirow[b]{2}{*}{$\begin{array}{l}\text { (At Seedling Stage) } \\
\text { Percent Stocking }\end{array}$} & \multicolumn{2}{|c|}{ (At Maturity) } \\
\hline & & No. of Trees/Acre & $\begin{array}{c}\text { Basal Area/Acre }{ }^{1} \\
\text { gq. ft. }\end{array}$ \\
\hline Badly understocked & under 20 & $75-120$ & $40-50$ \\
\hline Understocked & $20-50$ & $150-250$ & $70-90$ \\
\hline Well stocked & $50-80$ & $300-400$ & $100-120$ \\
\hline Overstocked & $100^{2}$ & $500+$ & $140+$ \\
\hline
\end{tabular}

Productivity

Wood volume by species of existing stands is compiled in Table 2. Estimates for both the present and potential wood production also by species are presented in Table 3.

The present mean annual production (MAI) values were obtained from 6,956 random relascope sample plot measurements distributed in all natural cover types. These results have been co-ordinated with the existing increment data obtained from growth and yield surveys carried out in the past.

The formula $\mathrm{V}=\frac{\mathrm{bD}^{2}}{100} \times \mathrm{H}$ was chosen to calculate the merchantable cubic foot volume of a single tree where:

$\mathrm{b}=$ regression coefficient calculated for each species and d.b.h. class.

$\mathrm{D}=$ diameter at breast height - o.b.

$\mathbf{H}=$ total tree height.

Three site quality groups, and 20-year age class intervals, were used in the computer compilations of the number of trees, basal area and wood volume per acre; and the same sub-divisions were maintained in the calculation of current and mean annual increment for each cover type unit.

This data, when adjusted to local standards of well stocked stands and modified for better or poorer than average sites, formed the guidelines for the forest land productivity rating.

The establishment of proper rotation ages for the maximum wood production of merchantable cubic foot volume was a further logical step in the

1) Only merchantable trees $4^{\prime \prime}$ d.b.h. and up are included.

2) When associated with a high number of trees per acre. 
procedure. It might be of interest to list these critical age limits and the corresponding MAI arrived at in Saskatchewan, to compare them with information for the same species from similar climatic regions. These flgures, relating to well stocked stands and average sites in this Province are shown below:

\begin{tabular}{lcc} 
Tree Species & Rotation Age (Yrs.) & MAI (cu. ft./A) \\
\hline White Spruce & 90 & 37 \\
Black Spruce & 100 & 18 \\
Jackpine & 70 & 33 \\
Aspen & 65 & 40 \\
Spruce-Aspen type & 85 & 45 \\
Aspen-Spruce type & 80 & 47
\end{tabular}

Ratings of land capability or potential are based on the breakdown of the land surface into geographic divisions or units, by inspection of aerial photographs, that are relatively uniform with respect to the more stable features of landform, as reflected in slope, surficial geology, soil and vegetation (4). With supplementary ground survey, each of these units is then assigned a capability class which implies a certain productivity. Productivity classes, based on the mean annual increment of the species best adapted to the site at or near rotation age, are expressed in gross merchantable cubic foot volume to a minimum diameter of four inches at breast height. Thinnings, bark and branchwood are not included. Normal or well stocked stands are implied.

For the benefit of readers who are not familiar with the land capability classes used in The Canada Land Inventory. Program of ARDA, the following is a condensed version (5):

Class 1: Lands in this class have no important limitations to the growth of commercial forests.

Productivity will usually be from 111 to 130 cubic feet per acre per year. When required, this class may be subdivided on the basis of productivity into Classes $1 \mathrm{a}(131$ to 150$) ; \mathrm{lb}(151-170)$ and by 20 cubic foot classes thereafter.

Class 2: Lands have slight limitations to the growth of commercial forests. Productivity will usually be from 91 to 110 cubic feet per acre per year.

Class 3: Lands in this class have moderate limitations to the growth of commercial forests.

Productivity will usually be from 71 to 90 cubic feet per acre per year.

Class 4: Lands may have moderate severe limitations to the growth of commercial forests.

Productivity will usually be from 51 to 70 cubic feet per acre per year.

Class 5: Lands have severe limitations to the growth of commercial forests. Productivity will usually be from 31 to 50 cubic feet per acre per year.

Class 6: Lands have severe limitations to the growth of commercial forests. Productivity will usually be from 11 to 30 cubic feet per acre per year.

Class 7: Lands will have limitations of such a severe nature as to preclude the growth of commercial forests. Productivity will usually be less than 10 cubic feet per acre per year. 
The limiting factors to growth or production are grouped by the factors of climate, soil moisture, permeability and rooting depth, fertility or high levels of toxic elements, stoniness, inundation, actual erosion, etc.

In calculating the potential production, the mid point of each productivity class was used and applied on an areal base exactly coincident with that area to which present or actual forest inventory figures were applied.

By comparison, the potential production of the area examined is 2.65 times that of present production. In other words, this area of forest land is capable of producing 44.4 million cubic feet of wood annually instead of the 16.8 million cubic feet which it now yields. Expressed as average production values in cubic feet per acre per year, the comparison is:

Potential - 38.4 cubic feet. Present -14.5 cubic feet.

The great difference shown in these figures is due mainly to understocking or overstocking; the usual condition in natural unmanaged forests. Some 78,000 acres of productive land have remained unforested. Present conditions have been aggravated by past and present utilization practices, coupled with a disregard of sites, which in combination with natural disturbances, has resulted in the present state of the forest.

Besides the difference in productivity, a noticeable difference exists between the present and the recommended distribution of tree species on the same land.

The Land Capability Survey of 1966 related site to tree species on the basis of:

1. species best suited ecologically to the site.

2. species with the highest yield.

3. species with the highest commercial value at present.

If commercial considerations should favour a different choice of species in the future, an intelligent judgment and choice between commercial prospects and prevailing limitations of local environments will be necessary. This survey provides a sound base for proper species selection in future management.

\section{Discussion}

We are accustomed, in Canadian forestry, to deal with available, natural forests. Occasionally, the productivity of a natural stand is at a maximum, thus the potential of a site is realized but in numerous cases natural stands reflect neither the best species composition, nor the potential of the land on which they are growing.

Forest and farm crops differ in many respects, but both are indisputably dependent on the land and its productivity. A farmer knows the potential or highest possible crop yield he can expect from his land at a certain level of management, given a certain acreage, and climatic conditions. $\mathrm{He}$ co-ordinates his efforts towards attaining this goal.

Similar considerations, whether recognized or not, have been imposed on forest managers. In forestry, however, the search has been directed towards more economical means in forest production and utilization. Wood harvesting and transportation costs are the biggest items in wood processing (reaching 40 percent to 50 percent of total expenses), and the stress lately has been to reduce these expenses through large scale production and mechanization. This, we have to admit, has had good success, especially in transport. Me- 
chanization has another advantage in that it lends itself most favourably to different innovations and improvements, and lucidly demonstrates all gains in exact units of time or money. Biological gains are much more difficult to assess.

If economic gain is the governing interest in forestry, it makes one wonder whether or not mechanization is the only major field in which to look for reduction of costs. In the case of agriculture, it is easy to foresee that complete mechanization would mean little if not used in balance with other factors, and particularly with soil productivity.

One can only speculate or make approximations at the present time as to how much a forest producer would gain if his lease area were reduced to one half of the present and the timber volume it presently supports would be doubled or tripled. Savings made on fire protection, land taxes, road construction, logging, transportation and other production costs might amply exceed the long-term low-interest capital investment in intensively managed forest land.

The authors are convinced that an immense economic source - the

TABLE 1

Area of Forest Cover Types, Map Sheet 73H, Prince Albert, Sask. (in acres)

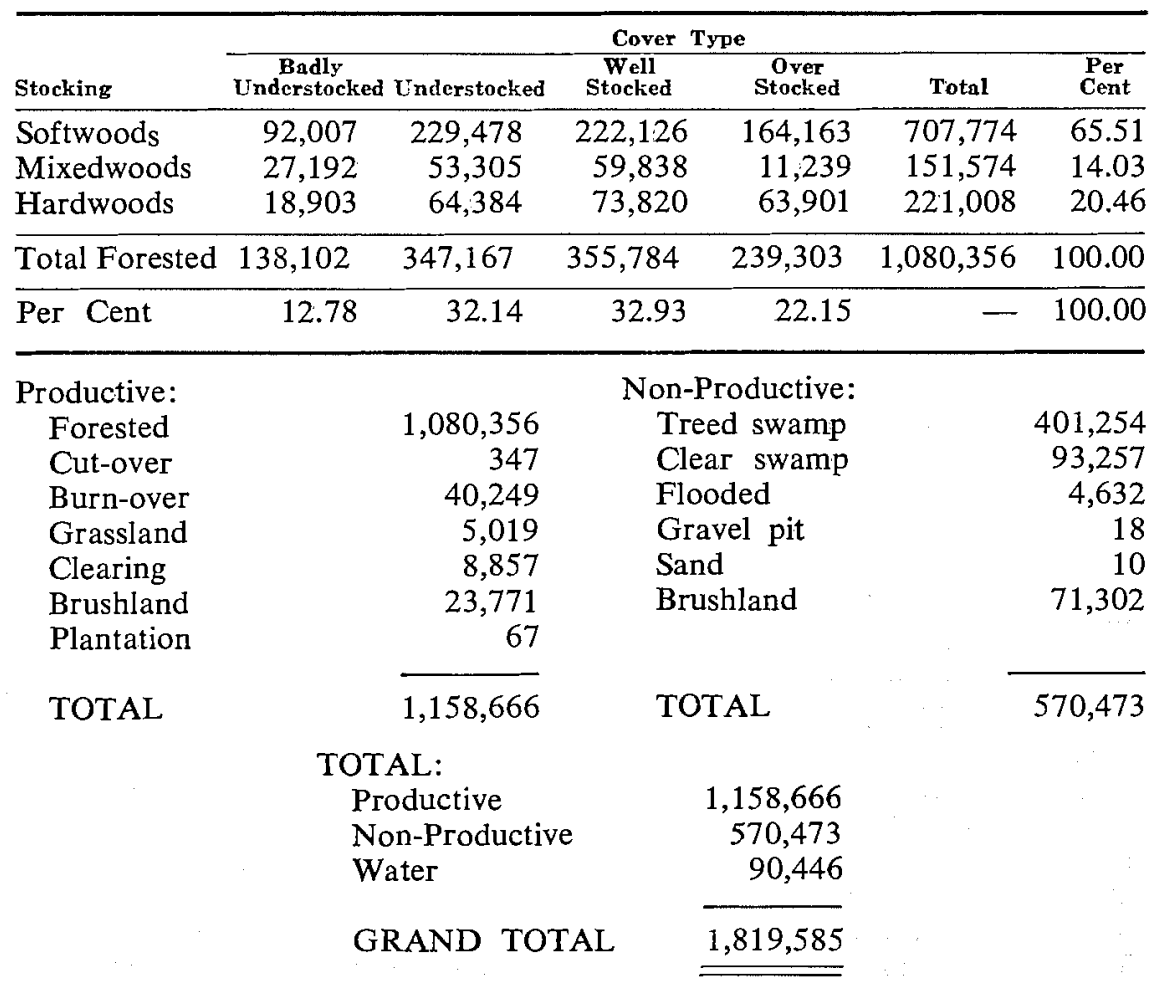




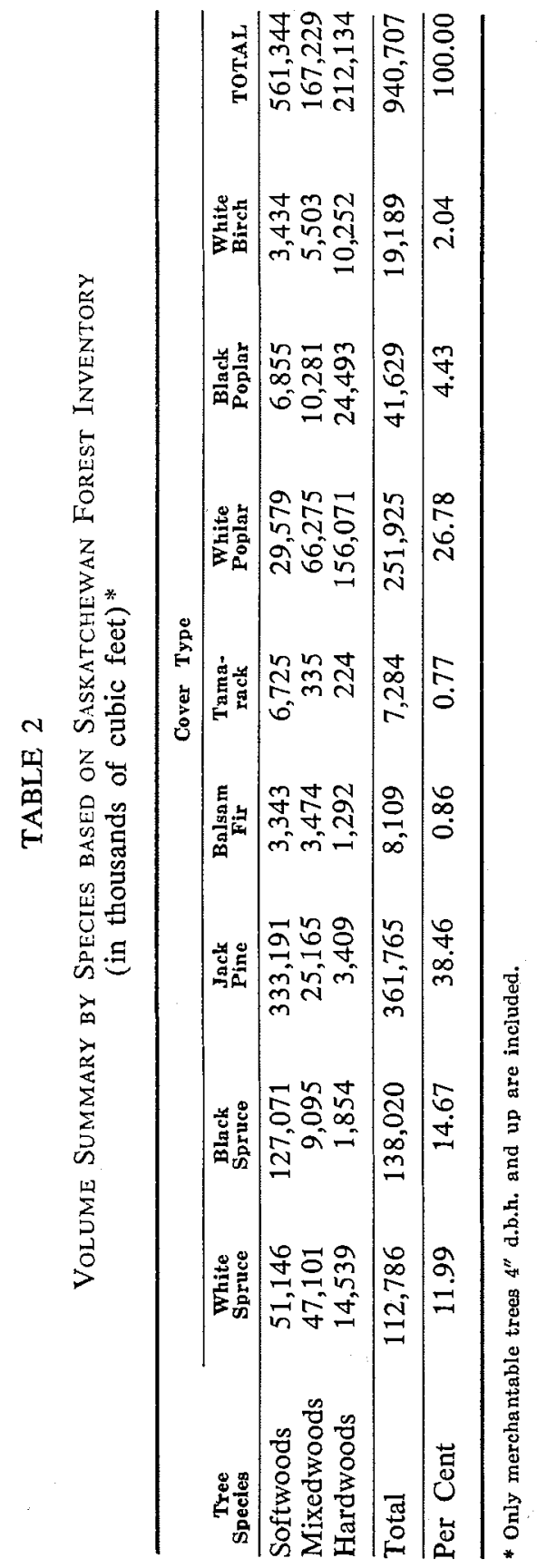


potential productivity of forest land, has not been adequately, if at all, recognized and utilized in our present-day forest management practices. Perhaps the present Land Capability for Forestry Survey will open channels to more advanced management in the future.

TABLE 3

Present and Potential Annual Production (in thousands of cubic feet) ${ }^{1}$

\begin{tabular}{lccccc}
\hline & \multicolumn{2}{c}{ Present Production } & & \multicolumn{2}{c}{ Potential Production } \\
\cline { 2 - 6 } \multicolumn{1}{c}{ Tree Species } & $1,567^{*}$ & Per Cent & & Cubic Feet & Per Cent \\
\hline White Spruce & 1,628 & 9.35 & $10,923^{*}$ & 24.58 \\
Black Spruce & 6,987 & 41.66 & & 6,603 & 14.86 \\
Jack Pine & 100 & 0.60 & & - & 57.16 \\
Balsam Fir & 177 & 1.06 & & - \\
Tamarack & 10,453 & 62.38 & 42,945 & 96.64 \\
\hline Total Softwoods & 5,069 & 30.25 & 1,282 & 2.88 \\
\hline Aspen & 883 & 5.27 & 212 & 0.48 \\
Black Poplar & 353 & 2.10 & - & - \\
White Birch & 6,305 & 37.62 & 1,494 & 3.36 \\
\hline Total Hardwoods & 16,758 & 100.00 & 44,439 & 100.00 \\
\hline Grand Total & & &
\end{tabular}

1. Only merchantable trees $4^{\prime \prime}$ d.b.h.-o.b. and up, have been included, as in Table 2 .

* The variation between present and potential production figures, especially of the commercially valuable softwood species, is explained by the fact that a good deal of land presently under aspen, black poplar and white birch was rated to softwoods. Along with this increase in softwood acreage, the land itself was given a potential productivity rating (generally higher than feet per year is $10,923,000$. This figure contains not only the effects of increased acreage, but also an expression of the potential of the land productivity.

\section{REFERENCES}

1. ACTON, D. F. et al; W. O. KUPSCH - Physiographic Divisions of Saskatchewan (Map - 1960).

2. CLAYTON, J. S. A manuscript describing the physiographic divisions of Saskatchewan. Unpublished report.

3. GIMBARZEVSKY, P. Land Inventory Interpretation. Reprint from Photogrammetric Engineering, Nov. 1965, pp. 967-976.

4. LACATE, D. S. Forest Land Classification for the University of British Columbia Research Forest. Publ. Dept. For. Can. No. 1107. 1965. pp. 25.

5. McCORMACK, R. J. Outline of the Canadian Land Capability Classification for Forestry. Prepared for Canada Land Inventory, ARDA 1965.

6. MOSS, H. C. A Guide to Understanding Saskatchewan Soils. Saskatchewan Institute of Pedology. Publication MI, 1965.

7. ROWE, J. S. Forest Regions of Canada. Bull. For. Br. Can. No. 123, 1959. pp. 71.

8. ROWE, J. S. Soil, Site and Land Classification, For. Chron. 38(4). 1962. pp. 420-431.

9. Saskatchewan's Forests, Dept. of Natural Resources, Regina, 1955.

10. Saskatchewan's Forest Inventory, 1947-1956, Department of Natural Resources, Regina, 1959. 